Історико-політичні проблеми сучасного світу: Збірник наукових статей. - Чернівці:

Чернівецький національний університет, 2020. - T. 42. - C. 27-35

DOI: $10.31861 / \mathrm{mhpi} 2020.42 .27-35$

УДК 327(4+477+(470+57))
Modern Historical and Political Issues: Journal in Historical \& Political Sciences. - Chernivtsi: Chernivtsi National University, 2020. - Volume. 42. - pp. 27-35 DOI: $10.31861 / \mathrm{mhpi} 2020.42 .27-35$

\title{
Позиції країн Вишеградської групи в політиці СС щодо України в умовах російсько-української війни
}

Стаття є спробою дослідити позиції країн Вишеградської групи в політиці ЄС щодо України в умовах російсько-української війни. Зазначено, що російсько-українська війна створила принципово нову ситуацію не лише в Україні, а й у Європі. Доведено, що країни Вишеградської групи активізували діяльність націлену на те, щоб українське питання міцно закріпилося на порядку денному в європейських інституціях. 3'ясовано внесок Польщі під час врегулювання російсько-української війни. Окреслено фактори, які впливали на зацікавлення Варшави українським питанням. Проаналізовано позицію Угорщини, Чехії та Словаччини щодо російськоукраїнської війни. Доведено, що найбільш принципову позицію щодо подій в Україні висловлювала Польща. Обгрунтовано думку про те, що позиції Угорщини та Чехії є відверто проросійськими та прагматичними, а Словаччини - поміркованими та мінливими. Війна на Сході України демонструє, що наразі серед країн Вишеградської групи немає чіткої і головне спільної позиції щодо України та її болючих проблем.

Ключові слова: Вишеградська четвірка, СС, східна політика, Україна, російсько-українська війна

\section{The Positions of the Visegrad Group States on the European Union Policy Towards Ukraine in the Context of the Russo-Ukrainian War}

The article analyses the positions of the Visegrad Group states on the European Union policy towards Ukraine in the context of the Russo-Ukrainian War. The relevance of the study is associated with the Visegrad Group states' significant role in the formation and implementation of the EU's modern Eastern policy. After becoming the EU members and achieving the main goal declared in the Visegrad Declaration of February 15, 1991, the Visegrad Group states did not abandon their joint effort within the framework of the regional union. Instead, they intensified their support for the European integration aspirations of their neighbouring countries, namely Ukraine. Being united in their positions on many issues important for the EU and Ukraine, the Visegrad Group has achieved tangible results. The Visegrad Group states supported Ukraine's European aspirations despite its obvious struggle with the pace and quality of reforms and the level of democracy, corruption and prosperity in the country. They ensured that Ukraine was on the EU's agenda and used the available resources and opportunities to keep the discussion on Ukraine going among the top decision-makers of the EU, especially after the Revolution of Dignity. All of the Visegrad Group states supported the EU-Ukraine Association Agreement and the decision to allow visa-free travel for Ukrainians.

However, the Visegrad Group states had differing views on the Russo-Ukrainian conflict. For example, Poland's rigid and uncompromising stance differed from the cautious and sometimes ambiguous positions of Hungary, Slovakia and the Czech Republic. Thus, the article aims to determine the differences among the positions of the Visegrad Group states regarding the EU's policy towards Ukraine in the context of the Russo-Ukrainian conflict. Ultimately, the Visegrad Group failed to reach the consensus on the Russo-Ukrainian War and sanctions against the aggressor. Differing views on the Russo-Ukrainian War clearly demonstrate lack of unanimity. Thus, the divergent reactions of the Visegrad Group states signal their inability to act as an in-house advocate for the EU's Eastern neighbours and, in general, weaken the EU's ability to implement its Eastern policy effectively.

Keywords: the Visegrad Group, EU, eastern policy, Ukraine, the Russo-Ukrainian War.

\footnotetext{
${ }^{1}$ Викладач кафедри міжнародних відносин Національного університету «Острозька академія», Україна. E-mail: krasnostaw@ukr.net; https://orcid.org/0000-0002-2206-4289.
} 
Постановка наукової проблеми та її значення. Дослідження позицій країн Вишеградської четвірки в політиці ЄС щодо України викликає значний суспільний інтерес. У першу чергу це пов'язано із вагомою роллю країн Вишеградської групи у формуванні та реалізації сучасної східної політики ЄС. Країни V4 після набуття членства у ЄС і досягнення головної цілі задекларованої у Вишеградській декларації 15 лютого 1991 р. не припинили свою спільну діяльність в рамках регіонального об'єднання, а навпаки активізували роботу з підтримки євроінтеграційних прагнень своїх сусідів, передусім України. Демонструючи єдність позицій у багатьох важливих питаннях для ЄС та України, держави Вишеградської групи досягли справді високих успіхів. Але в умовах російсько-української війни країни Вишеградської групи розділилися у своїх поглядах щодо країни-агресора. Від найбільш жорстких і принципових позицій Польщі, до стриманих і навіть неоднозначних реакцій на російську агресію з боку Угорщини, Словаччини i Чехії.. Різноманітність голосів та реакцій із країн V4 ставить під сумнів їхню спроможність діяти як внутрішній адвокат у ЄС для східних сусідів та послаблює здатність ЄС у цілому ефективно реалізовувати його східну політику.

Аналіз останніх досліджень та публікацій. Окремим аспектам діяльності країн Вишеградської групи, їх участі у європейських проєктах, співпрацю із країнами Східного партнерства, а також діяльність V4 в умовах російсько-української війни приділено увагу багатьох зарубіжних та вітчизняних дослідників. Серед зарубіжних вчених виділимо праці М. Машкевича, Т. Стемпнєвського, Д. Мільчарека, П. Кратохвіля, Е. Тульмець та ін. Серед вітчизняних науковців, які досліджували вказану проблематику назвемо Г. Перепелицю, А. Круглашова, Т. Сидорук, О. Добржанську (Шородок), О. Шаповалову, Т. Жовтенка.

Мета статті - проаналізувати позиції країн Вишеградської групи в політиці СС щодо України в умовах російсько-української війни. В роботі виділено низку завдань: дослідити позицію Польщі щодо російсько-української війни, проаналізувати погляди Чехії щодо учасників російсько-українського збройного протистояння, з'ясувати особливості політики Угорщини у питанні кваліфікації дій РФ на території України та простежити позицію Словаччини щодо збройної агресії РФ в Україні.

Виклад основного матеріалу. Із початком російської агресії в Україні, незаконного захоплення Криму та окупації двох областей увесь світ, а також країни V4, були стурбовані порушенням міжнародного права Росією та активізували діяльність з метою допомоги Києву.

Країни Вишеградської групи здійснили справжній наступ з українського питання на рівні V4 та ЄС. Свідченням цього було те, що лише за 2014 р. $з 21$ найбільш значущих документів, схвалених та оприлюднених у V4, 9 безпосередньо адресувалися чи стосувалися України. Було організовано цілу низку дипломатичних зустрічей у ході яких країни V4 закликали ЄС виділити фінансову допомогу Україні, засуджували дії РФ та дискутували щодо шляхів мирного врегулювання війни.

Зокрема, 27 лютого 2014 р. у Будапешті зустрілися представники парламентів країн V4, які обговорили події в Україні та висловили занепокоєння щодо подій у Кримуㄹ․ 4 березня 2014 p. прем'єр-міністри країн V4 зробили спільну заяву щодо України, у якій висловили глибоку стурбованість порушенням територіальної цілісності України та тим, що російський парламент санкціонував військові дії на українських територіях.

Вагомим досягненням в контексті консолідації зусиль країн Вишеградської групи був спільний лист від імені чотирьох міністрів зовнішніх справ до Високого представника зовнішніх справ та політики безпеки ЄС К. Ештон та Єврокомісара з питань розширення та ЄПС Ш. Фюле від 5 березня 2014 р. Автори листа наголосили на тому, що зважаючи на розвиток подій в Україні, на позитивну динаміку у сфері внутрішніх реформ, ЄС має виконати свій моральний обов'язок щодо України та розпочати підготовку до підписання Угоди про асоціацію України 3 $\mathrm{EC}^{3}$.

Міністри V4 присвятили спеціальну зустріч українському питанню 30 жовтня 2014 р. (м. Братислава, Словаччина). Дипломати спільно обговорили проблеми російсько-української вій-

\footnotetext{
2 Joint Statement on Ukraine of the Parliamentary Speakers of the Visegrad Countries Budapest, 28 February 2014. URL: http://www.visegradgroup.eu/calendar/2014 (дата звернення: 15.10.2018).

3 Joint V4 Foreign Ministers' Letter on Ukraine to Ashton and Füle. URL: http://www.visegradgroup.eu/ calendar/2014 (дата звернення: 12.01.2020).
} 
ни та підкреслили вирішальну роль, яку, на їх погляд, відіграє ОБСЄ у моніторингу та перевірці виконання Мінських угод. Міністри країн V4 запевнили, що будуть продовжувати співпрацювати з партнерами та союзниками для надання різних форм конкретної допомоги Україні ${ }^{4}$.

30 жовтня 2014 р. відбувся ще один захід за участі країн V4, Міністра закордонних справ Сполученого Королівства Великобританії та Північної Ірландії. Учасники напрацювали спільну заяву щодо місцевих виборів на Донбасі, які були заплановані на 2 листопада 2014 р. У тексті оприлюдненого документу читаємо відверте засудження намірів провести місцеві вибори у регіоні Донбасу. Міністри вважали такі вибори нелегітимними та такими, що суперечать Мінському протоколу (підписаний 5 вересня 2014 р.) і закликали міжнародну спільноту не визнавати $\mathrm{ix}^{5}$.

Загострення ситуації в Україні пришвидшило створення спільного батальйону Вишеградської групи, угоду про створення якого було досягнуто міністрами оборони в травні 2011 p. ${ }^{6} .3$ 2014 р., після Революції Гідності в Україні, батальйон зміцнився за рахунок об’єднаного військового командування.

У Братиславській декларації зазначалося, що у зв’язку з агресивними діями Росії щодо України країни Вишеградської групи почнуть координувати свої національні позиції з метою максимізації зусиль щодо підтримки України. Крім того було підтверджено участь українців у Вишеградському батальйоні, починаючи 3 першої половини 2016 р.7. На думку 3. Дубського, батальйон створив додаткову сферу взаємодії країн Вишеградської групи і відчуття додаткової захищеності в сучасній нестабільній міжнародній ситуації8.

Усі без винятку країни Вишеградської групи надавали суттєву фінансову підтримку Україні. Зокрема, вони долучилися до фінансування Вишеградської стипендійної програми для країн Східного партнерства з Міжнародного Вишеградського фонду. Детальну інформацію про обсяги фінансування України в рамках згаданої програми можна знайти у таблиці 1.

\section{Таблиия 1}

Обсяг фінансування України у рамках Вишеградської стипендійної програми для країн Східного партнерства Міжнародним Вишеградським фондом (євро)

\begin{tabular}{|c|c|c|c|c|c|c|c|}
\hline \multirow[t]{2}{*}{$\begin{array}{c}\text { Країни } \\
\text { Вишеградської } \\
\text { четвірки }\end{array}$} & \multicolumn{6}{|c|}{$\begin{array}{c}\text { Обсяг фінансування України у рамках Вишеградської } \\
\text { стипендійної програми для країн Східного партнерства } \\
\text { Міжнародним Вишеградським фондом, свро. }\end{array}$} & \multirow[t]{2}{*}{$\begin{array}{l}\text { Всього } \\
\text { за увесь } \\
\text { період, } \\
\text { свро } \\
\end{array}$} \\
\hline & 2012 & 2013 & 2014 & 2015 & 2016 & 2017 & \\
\hline Польща & 57000 & 57000 & 91200 & 102600 & 45600 & 68400 & 421800 \\
\hline Словаччина & 57400 & 57200 & 125400 & 110400 & 129200 & 68400 & 548000 \\
\hline Угорщина & 57000 & 57000 & 83600 & 95000 & 83600 & 87400 & 463600 \\
\hline Чехія & 58200 & 57200 & 80600 & 102800 & 49800 & 91800 & 440400 \\
\hline Всього за рік & 229600 & 228400 & 380800 & 410800 & 308200 & 316000 & 1433400 \\
\hline
\end{tabular}

Складено автором на основі: Дані з офіційного сайту Міжнародного Вишеградського фонду. URL: https://www.visegradfund.org/archive/results/visegrad-scholarship-program-eap/ (дата звернення: 10.04.2020).

\footnotetext{
${ }^{4}$ The Joint Statement of the Visegrad Group Foreign Ministers on Ukraine. URL: http://www.visegradgroup.eu/ calendar/2014/the-joint-statement-of (дата звернення: 12.01.2020).

${ }^{5}$ Joint Statement of the MFAs of the Visegrad Group Countries together with the Minister of Foreign Affairs of the United Kingdom of Great Britain and Northern Ireland to the Local Elections in Donbas held on November 2, 2014. URL: http://www.visegradgroup.eu/calendar/2014/joint-statement-of-the (дата звернення: 12.01.2020).

${ }^{6}$ Фесенко М. (2017), Феномен Вишеградської групи в європейському політичному процесі. Вісник Киівського начіонального університету імені Тараса Шевченка Міжнародні відносини. Київ, 1/2 (47/48). C. 16.

${ }^{7}$ Там само.

${ }^{8}$ Dubsky Z. (2013), Visegrad Cooperation in Military and Security Areas. Is Visegrad still a Central European «Trade Mark»? Bratislava, P. 58.
} 
Більш наочно простежити осібний внесок фінансових інвестицій кожної країни Вишеградської групи для України у рамках Вишеградської стипендійної програми можна за допомогою рисунку 1.

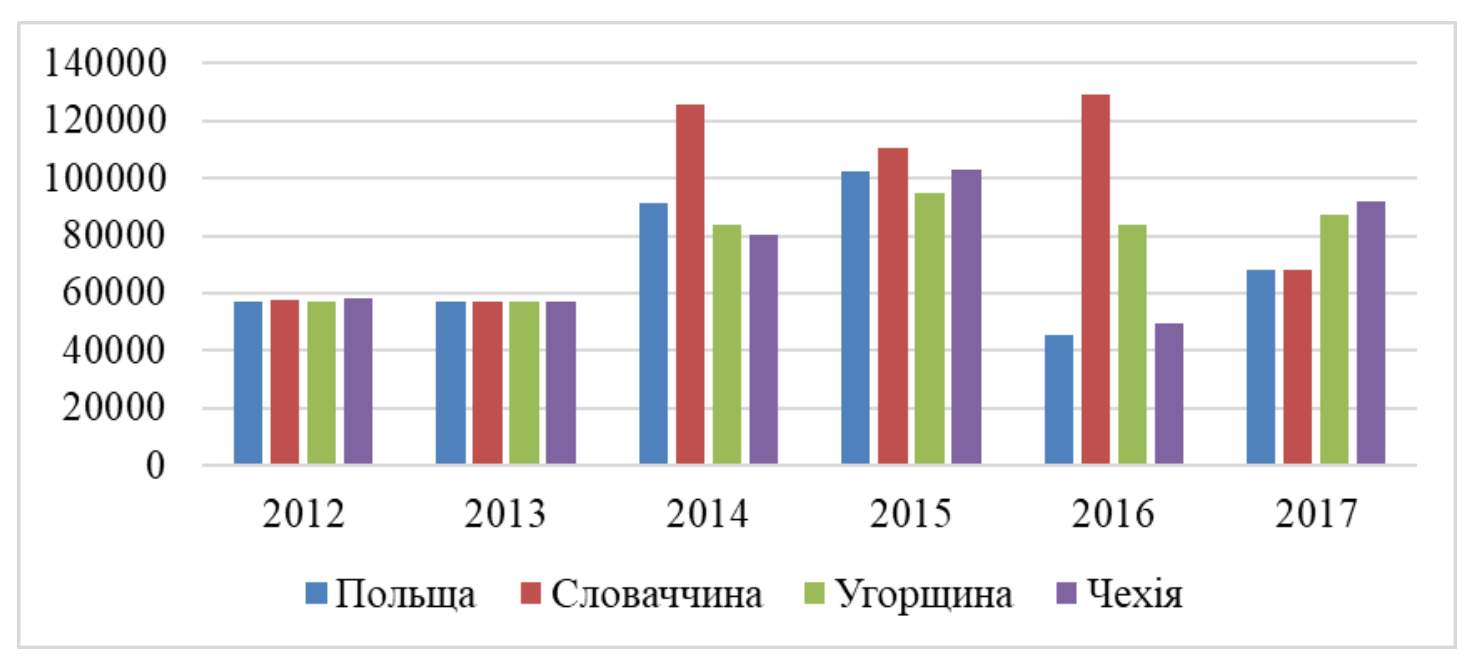

Рис. 1. Динаміка обсягу фінансування Украӥни у рамках Вищеградської стипендійної програми для краӥн Східного партнерства Міжнародним Вищеградським фондом (євро)

Складено автором на основі: Дані з офіційного сайту Міжнародного Вишеградського фонду. URL: https://www.visegradfund.org/archive/results/visegrad-scholarship-program-eap/ (дата звернення: 10.04.2020).

Свою підтримку країни Вишеградської групи висловлювали під час самітів Східного партнерства, які відбувалися в умовах російсько-української війни. Втім, вплинути на позитивний хід Ризького саміту Східного партнерства ( 21-22 травня 2015 р.) не вдалося, бо саміт не став проривом для України в контексті ухвалених у підсумковій декларації рішень.

У Брюссельському саміті Східного партнерства (24 листопада 2017 р.) Україна брала участь уже маючи безвіз (з 11 червня 2017 р.). Для того щоб надання безвізового режиму з СС для України стало реальністю країни V4 також доклали значних зусиль. Спільним успіхом цілком можна вважати ратифікацію Угоди про асоціацію з СС включно із створенням поглибленої і всеосяжної зони вільної торгівлі, яка набула чинності напередодні - з 1 вересня 2017 p.

Однак, незважаючи на чималі успіхи у підготовчому етапі саміт у Брюсселі став для України самітом підбиття підсумків. 3 цього приводу, посилаючись на текст підсумкової декларації, можна сказати, що це був саміт «без перспективи» тим паче, що в контексті перспектив членства в СС для країн Східного партнерства не було надано жодних можливостей ${ }^{9}$

На наш погляд, на результатах Брюссельського саміту позначилась зміна тональностей у відносинах України з Угорщиною, Польщею, а також те, що країни V4 змінили свою тактику щодо активності у просуванні українського питання у 2017 - 2018 pp. У тісному колі Вишеградської четвірки все частіше обговорюють «болючіші» питання: міграції в ЄС та запровадження міграційних квот, розширення ЄС за рахунок Західних Балкан, енергетичні та кліматичні проблеми.

Цілком прогнозовано, що черговий саміт Східного партнерства розглядатиме питання війни в Україні. Він запланований на 2021 рік і стане точкою відліку нових цілей та етапом підбиття підсумків про виконання, затверджених у 2017 р. «20 завдань Східного партнерства до 2020 р.».

Прикметно, що російсько-українська війна стала своєрідним лакмусовим папірцем, що показав позицію міжнародного оточення до сторін війни. Позиції щодо цього питання були різними і неоднозначними серед країн V4.

3 цього приводу слушною є думка Т. Сидорук про те, «що найбільш жорсткі і принципові позиції щодо «української кризи», приєднання Криму до Росії і подальшої військової кампанії

\footnotetext{
9 Joint Declaration of the Eastern Partnership Summit (Brussels, 24 November 2017). URL: http://www. consilium.europa.eu/media/31758/final-statement-st14821en17.pdf (дата звернення: 25.11.2017).
} 
на Донбасі зайняли Польща та держави Балтії... На відміну від них, реакція країн південної частини Центральної Свропи на події в Україні була більш стриманою. Вона варіювалася від обережного засудження дій Росії Болгарією, початкового помітного дистанціювання від цієї проблематики в Румунії, до тихого прагматизму у Словаччині та чітких проросійських голосів у Чеській Республіці та Угорщині. Представники цих країн на засіданнях Ради ЄС або відмовчувалися з українського питання, або займали невизначені чи не надто проукраїнські позиції» ${ }^{10}$.

Кожна з цих країн має своє пояснення та обгрунтування власної позиції. Так, Польща асоціює свою безпеку з безпекою на кордонах з РФ, а тому їхній інтерес у мирній, стабільній та безпечній Україні є закономірним. Саме тому Польща демонструвала найбільш безкомпромісну позицію щодо оцінки подій у Криму та на Донбасі як анексії та військової агресії, запровадження санкцій щодо Росії ${ }^{11}$.

3 перших днів війни в Україні Польща надавала політичну підтримку, фінансову, військову, гуманітарну та медичну допомогу українцям. До цього процесу була залучена не лише влада, а й громадськість, зокрема журналісти, медики, військові, волонтери тощо.

Польща виділила 100 млн. євро кредитної допомоги Україні, на 2,5 млн. євро профінансовано стипендійні програми для студентів з Донецької, Луганської областей та Криму (на 2015 р.). Польська сторона у кілька етапів надавала гуманітарну допомогу та здійснювала фінансування на лікування та реабілітацію українських військових спочатку на суму 1 млн. дол., на 170 тис. євро та 350 тис. грн. ${ }^{12}$.

Польща була донором України в рамках Вишеградської стипендійної програми для країн Східного партнерства 3 Міжнародного Вишеградського фонду. За час існування програми 3 2012 по 2017 рр. Польща виділила понад 421 тис. євро для громадян України (детальніше див. таблицю А). Прикметно, що після подій в Україні кінця 2013 - початку 2014 р. обсяг польських інвестицій в рамках програми постійно зростав.

Рекордним роком польських асигнувань став 2015 р., коли Польща виділила для України понад 102000 євро, а рекордно низьку суму українці отримали у 2016 р., на що, очевидно, вплинуло погіршення українсько-польських відносин через історичне питання ставлення до подій Другої світової війни та трактування участі поляків та українців у взаємних масових етнічних чистках. Для нормалізації двосторонніх відносин вкрай важливо залишити політику політикам, а історію - історикам та продовжувати пошук спільних об'єднавчих тем. Бо якщо ситуація зі «спекуляцією пам'яті» збережеться, то $є$ усі підстави вважати, що попередньої підтримки України з боку Польщі очікувати не слід. Звісно, Варшава не діятиме на міжнародній арені всупереч своїм інтересам в енергетичних питаннях, будівництві «Північного потоку-2», але реалізацію програми Східне партнерство та підтримку санкцій щодо РФ може «переглянути».

Чехія висловлювала чи не найбільш суперечливі позиції щодо сторін війни в Україні, оскільки погляди на ситуацію президента М. Земана та очільника уряду Б. Соботка - були різними. М. Земан часто дозволяв собі висловлювання на кшталт того, що в Україні триває громадянська війна та не приховував політичних загравань із В. Путіним.

Попри те, що глава уряду більш поміркований у висловлюваннях, реальні кроки влади не свідчать про значну прихильність чи співпереживання Україні. Зокрема, Чехія останньою ратифікувала Угоду про асоціацію між Україною та ЄС, а також не підписала звернення країн Центральної та Східної Свропи проти побудови газопроводу «Північний потік-2» ${ }^{13}$.

Окрім владної верхівки Чехії, проросійські настрої притаманні і для значної частини населення країни. На це чинить вплив присутність російського капіталу в Чехії, і відповідно, економічних зв'язків з РФ, а також наявність профінансованих російських ЗМІ, які здійснюють перманентний викривлений вплив на об'єктивну свідомість частини громадян.

\footnotetext{
${ }^{10}$ Сидорук Т. (2015), Позиції держав-членів СС щодо російсько-українського конфлікту. Вісник Львівського університету. Серія: Міжнародні відносини. Львів, Вип. 36 (3). С. 15.

11 Жовтенко Т. (2018), Вишеградська четвірка і Україна: еволюція стосунків і їх сучасні безпекові виміри. Демократичний транзит в краӥнах Вишеградської групи та Украйні: вибрані аспекти. За ред. Д. Шевчука, В. Лебедюка. Вид-во Національного університету «Острозька академія», Острог. С. 197.

12 Як сусідні країни допомагають Україні протистояти російській агресії. URL: https://ua.112.ua/statji/Yaksusidni-krainy-dopomahaiut-Ukraini-protystoiaty-rosiiskii-ahresii-220695.html (дата звернення: 16.01.2020).

13 Чехи, як і чеська влада, поділені у ставленні до України. URL: https://www.radiosvoboda.org/ a/27497255.html (дата звернення: 16.01.2020).
} 
Чехія не лише висловлювала позицію щодо подій в Україні, а вважала, що тут триває громадянська війна та була проти запровадження санкцій проти Росії на початку осені 2014 р., наводячи економічні аргументи. Можливо ця ситуація і не зазнала б суттєвих змін, якби не позиція Німеччини щодо ситуації в Україні та запровадження санкцій. Тому від початку військового протистояння в Україні Чехія підтримала спільну позицію ЄС щодо України, підтримуючи іiі територіальну цілісність та санкції проти Росії. Але коли санкції почали завдавати економічних збитків державі, Чехія почала називати їх невиправданими та неефективними. У такій ситуації сам факт подальшої підтримки чинних санкцій можна вважати позитивним аспектом чеської політики щодо України.

Попри усю складність ситуації з проросійськи налаштованою позицією чеського керівництва, ця країна все ж таки не була осторонь під час допомоги Україні з часу російської агресії. Зокрема через Вишеградську стипендійну програму для країн Східного партнерства у рамках Міжнародного Вишеградського фонду Україна отримала від Чехії понад 440000 євро (детальніше див. таблицю А). У розрізі років, фінансування було найбільшим у $2014-2015$ pp.

Схожа проросійська риторика щодо російсько-української війни звучала від Угорщини. Населення та політичне керівництво країни хоч і підтримали європейську інтеграцію України, та все ж вважали, що успіх у цьому напрямку залежить від політичної та економічної стабільності всередині країни та здатності контролювати свої кордони.

Угорщина закликала до перегляду антиросійських санкцій, оскільки вони негативно впливали на економіку країни та розглядала Росію в контексті економічного співробітництва, а не політики безпеки ${ }^{14}$. Принагідно згадати, що на початку осені 2014 р. Угорщина разом із Чехією та Словаччиною були проти запровадження санкцій. На це суттєво впливало те, що Угорщина має тісні економічні зв'язки з РФ, а також залежна від російських енергоносіїв. Це стало на заваді формування регіонального енергетичного хабу у 2014 р., який підтримали Польща, Чехія та Україна. Угорщина зволікала зі своїм рішенням через інтерес до збереження російського газу у сховищах та будівництва газопроводу «Південний потік», хоча і розуміла важливість диверсифікації джерел та шляхів транспортування енергоносіїв ${ }^{15}$.

3 іншого боку, в Угорщині наявний значний німецький капітал, а тому ця країна так само залежна від позиції Німеччини у питанні кваліфікації військових дій в Україні. У такій ситуації, та ще за умови існування етнополітичних суперечностей з Києвом, Будапешт провадить гнучку політику, намагаючись догодити усім та не нашкодити собі.

Станом на 2015 р. Угорщина виділила 100 тис. євро на цільовий фонд НАТО для України та прийняла 20 українських військовослужбовців із зони АТО на лікування та реабілітацію. Через Вишеградську стипендійну програму для країн Східного партнерства у рамках Міжнародного Вишеградського фонду Угорщина надала Україні понад 463 тис. євро. Надалі Угорщина продовжувала надавати фінансову підтримку, але політичні пріоритети змістила у бік міграційних, енергетичних процесів у СС, співпраці із країнами Західних Балкан тощо.

Словаччина зайняла дистанційовану позицію щодо російсько-української війни. Зважаючи на те, що зі Словаччиною Україна не має територіальних чи етнічних суперечок, ситуація могла б розвиватися інакше, толерантніше.

Неоднозначну позицію Словаччини щодо воюючих сторін в Україні можна пояснити протилежними політичними поглядами ії політиків. Зокрема, прем'єр-міністр Р. Фіцо у 2014 р. висловився про «вирішеність питання Криму» та був проти зближення України з $\mathrm{HATO}^{16}$. Пізніше, у 2015 р., він мав наміри скласти компанію для М. Земана та відвідати урочистості з нагоди Дня перемоги та параду 9 травня у Москві.

Утім наступник Р. Фіцо - А. Кіска зайняв протилежну позицію та став на бік підтримки української сторони в російсько-українській війніi. Він не погодився прибути на парад 9 травня у Москву, засудив дії РФ в Україні та закликав В. Путіна вивести «іноземних солдатів зі Сходу України» ${ }^{17}$. На таку антиросійську позицію Словаччини у першу чергу впливає те, що в країні

\footnotetext{
${ }^{14}$ Як сусідні країни допомагають Україні протистояти російській агресії. URL: https://ua.112.ua/statji/Yaksusidni-krainy-dopomahaiut-Ukraini-protystoiaty-rosiiskii-ahresii-220695.html (дата звернення: 16.01.2020).

15 Жовтенко Т. (2018), вказ. пр., с. 194.

${ }^{16}$ Там само, с. 195.

17 Там само.
} 
присутній не російський, а німецький капітал, а отже словацькі політики солідарні 3 німецькими колегами щодо українського питання. Крім того, не останню роль у словацькій політиці відіграє енергетичний чинник. Саме Словаччина, на думку М. Фесенка, донедавна була основним «газоприймачем» $\mathrm{i}$ «газорозподільником» російських потоків на території не тільки Вишеградської групи, а й більшої частини $\mathrm{CC}^{18}$. Словаччина зацікавлена у транзиті російського газу через територію України. 3 цього приводу Т. Жовтенко зауважив, що «збільшення реверсу газу зі Словаччини до показника третини поточних потреб України, досягнення консенсусу з цією країною як сполучною газотранспортною ланкою в транзиті російської сировини нівелює неоднозначне сприйняття в словацькому суспільстві ролі Росії у військово-політичній кризі» ${ }^{19}$.

Варто зауважити, що Словаччина ініціювала побудову нового прикордонного пункту «Улич - Забрідь» та реконструкцію переходу «Вишнє Нємецьке - Ужгород». Братислава фінансово сприяла оздоровленню дітей із зони проведення АТО, а також виділила матеріальну допомогу у 2014 р. на суму 800 тис. євро, а в 2015 р. - на суму понад 700 тис. євро ${ }^{20}$. Крім того, Словаччина стала найбільшим донором України в рамках Вишеградської стипендійної програми для країн Східного партнерства. 3 початком війни на Сході України Словаччина обмежила фінансування інших країн Східного партнерства та направила суттєві обсяги матеріальної допомоги для українських громадян (детальніше див. таблицю А).

Висновки. Різниця у ставленні до російсько-української війни наочно демонструє проблеми у самій Вишеградській групі, хоча на початку своєї співпраці учасники планували провадити спільну активну зовнішню політику задля поширення демократії, забезпечення стабільності на кордонах та для зміцнення свого міжнародного середовища. Серед іншого країни Вишеградської групи мали на меті підтримувати європейські прагнення України та протидіяти поширеній серед країн «старої Свропи» ідеї «Russia the first».

Вони підтримали європейські прагнення України попри очевидні проблеми з темпами і якістю реформ, рівнем демократії, корупції та добробуту в країні. Вони створили умови для того, щоб важливі для України питання були включені до порядку денного в $Є С$ і використовували наявні ресурси і можливості, щоб сприяти їх вирішенню особливо після Революції Гідності. Усі вони підтримали угоду про асоціацію та рішення про надання безвізу для України.

Проте, країни Вишеградської групи провалили іспит на консенсус у питанні російськоукраїнської війни та санкцій проти країни-агресора. Різні погляди на російсько-українську війну виразно демонструють відсутність одностайності.

Польща демонструвала найбільшу активність у підтримці євроінтеграційних прагнень України. Варшава вітала євроінтеграційні прагнення українців, була прихильницею надання безвізового режиму, виступала за впровадження санкцій проти Росії, називаючи іiі країною-агресором, засуджувала порушення територіальної цілісності України. Крім того, Польща $є$ постійним фінансовим донором багатьох проєктів в Україні. Ї̈̈ позиція була і залишається найбільш чіткою та безкомпромісною.

Словаччина підтримала євроінтеграційні прагнення України та наголошувала на важливості проведення ефективних реформ. Для Словаччини Україна важлива з точки зору енергетичних питань проте, рівень зацікавленості Словаччини Україною не порівняти із польським, оскільки словацькі дипломати більш солідарні проблемам Європи. До того ж, позиція Словаччини 3 плином часу зазнавала суттєвих змін. Це простежувалося коли Словаччина висловила звинувачення Києву під час газової кризи (2009р.) та в поведінці політичної еліти країни. Зокрема, політичні вподобання проросійського прем'єр-міністра Р. Фіцо, який зайняв позицію підтримки Росії та засуджував впровадження санкцій, аргументуючи свою думку економічними збитками для Словаччини та «вирішенням питання Криму». Прихід до влади президента А. Кіски призвів до змін у ставленні до конфліктуючих сторін. Зокрема, він підтримав санкції проти Росії як країни-агресора, закликав очільника Кремля вивести з України «іноземних солдатів» та наголосив на важливості дотримання Мінських домовленостей. Словаччина стала найбільшим донором України в рамках Вишеградської стипендійної програми для країн Східного партнерства.

\footnotetext{
18 Фесенко М. (2017), вказ. пр., с.16.

19 Жовтенко Т. (2018), вказ. пр., с. 194.

20 Як сусідні країни допомагають Україні протистояти російській агресії. URL: https://ua.112.ua/statji/Yaksusidni-krainy-dopomahaiut-Ukraini-protystoiaty-rosiiskii-ahresii-220695.html (дата звернення: 16.01.2020).
} 
Угорщина підтримала проєкт Східне партнерство та позиціонує Україну як важливого партнера хоча наші двосторонні відносини, на жаль, обтяжені етнополітичними претензіями. Вплив російського капіталу на угорську економіку, небажання угорських політиків йти проти Кремля, а також залежність від поставок російських енергоносіїв накладає додатковий відбиток на формування єдиної позиції Угорщини щодо України.

3 початком російсько-української війни Угорщина все ж таки засудила дії РФ та підтримала впровадження санкцій. Наразі Угорщина надає перевагу участі у вирішенні міграційної кризи ЄС над інтенсифікацією співпраці України з СС.

Щодо російсько-українського збройного протистояння, Чехія зайняла відверто проросійську позицію. Це зумовлено не лише політичними симпатіями президента М. Земана, а й присутністю російського капіталу в країні, впливом Росії на чеські ЗМІ тощо. Виходячи 3 цього, Чехія висловлювала позицію, що в Україні відбувається громадянська війна, а санкції проти Росії зайвий тягар для чеської економіки. Не кваплячись, Прага все ж таки визнала, що винуватцем війни в Україні є РФ, та підтримала санкції проти останньої, але час від часу порушує питання в СС про їх послаблення.

Війна на Сході України демонструє, що наразі серед країн Вишеградської групи немає чіткої і головне спільної позиції щодо України та ії болючих проблем. Доводиться говорити не лише про відсутність консенсусу у питанні кваліфікації дій РФ на території України, санкцій щодо країни агресора, але й проте, що система колективної безпеки у Європі не надійна і не ефективна. На сьогодні вона залежна від економічних пріоритетів впливових країн $Є С$ та геополітичної кон’юктури в цілому.

\section{Список джерел}

1. Дані $з$ офіційного сайту Міжнародного Вишеградського фонду. URL: https://www. visegradfund.org /archive/results/visegrad-scholarship-program-eap/ (дата звернення: 10.04.2020).

2. Жовтенко Т. (2018), Вишеградська четвірка і Україна: еволюція стосунків і їх сучасні безпекові виміри. Демократичний транзит в краӥнах Вишеградської групи та Украӥні: вибрані аспекти. За ред. Д. Шевчука, В. Лебедюка. Вид-во Національного університету «Острозька академія», Острог. С. 190-202.

3. Сидорук Т. (2015), Позиції держав-членів ЄС щодо російсько-українського конфлікту. Вісник Львівського університету. Серія: Міжнародні відносини. Львів, Вип. 36 (3). С. 13-19.

4. Фесенко М. (2017), Феномен Вишеградської групи в європейському політичному процесі. Вісник Київського начіонального університету імені Тараса Шевченка Міжнародні відносини. Київ, 1/2 (47/48). С. 13-18.

5. Чехи, як і чеська влада, поділені у ставленні до України. URL: https://www. radiosvoboda.org/a/27497255.html (дата звернення: 16.01.2020).

6. Як сусідні країни допомагають Україні протистояти російській агресії. URL: https:// ua.112.ua/statji/Yak-susidni-krainy-dopomahaiut-Ukraini-protystoiaty-rosiiskii-ahresii-220695.html (дата звернення: 16.01.2020).

7. Dubsky Z. (2013), Visegrad Cooperation in Military and Security Areas. Is Visegrad still a Central European «Trade Mark»? Bratislava, P. 56-73.

8. Joint Declaration of the Eastern Partnership Summit (Brussels, 24 November 2017). URL: http://www.consilium.europa.eu/media/31758/final-statement-st14821en17.pdf (дата звернення: 25.11.2017).

9. Joint Statement of the MFAs of the Visegrad Group Countries together with the Minister of Foreign Affairs of the United Kingdom of Great Britain and Northern Ireland to the Local Elections in Donbas held on November 2, 2014. URL: http://www.visegradgroup.eu/calendar/2014/jointstatement-of-the (дата звернення: 12.01.2020).

10. Joint Statement on Ukraine of the Parliamentary Speakers of the Visegrad Countries Budapest, 28 February 2014. URL: http://www.visegradgroup.eu/calendar/2014 (дата звернення: 15.10.2018).

11. Joint V4 Foreign Ministers' Letter on Ukraine to Ashton and Füle. URL: http://www.visegradgroup.eu/calendar/2014 (дата звернення: 12.01.2020).

12. The Joint Statement of the Visegrad Group Foreign Ministers on Ukraine. URL: http://www.visegradgroup.eu/calendar/2014/the-joint-statement-of (дата звернення: 12.01.2020). 


\section{References}

1. Dani z ofitsiinoho saitu Mizhnarodnoho Vyshehradskoho fondu. URL: https://www.visegradfund.org/archive/results/visegrad-scholarship-program-eap/ (data zvernennia: 10.04.2020)

2. Zhovtenko T. (2018), Vyshehradska chetvirka i Ukraina: evoliutsiia stosunkiv i yikh suchasni bezpekovi vymiry. Demokratychnyi tranzyt $v$ krainakh Vyshehradskoi hrupy ta Ukraini: vybrani aspekty. Za red. D. Shevchuka, V. Lebediuka. Vyd-vo Natsionalnoho universytetu «Ostrozka akademiia», Ostroh. S. 190-202.

3. Sydoruk T. (2015), Pozytsii derzhav-chleniv YeS shchodo rosiisko-ukrainskoho konfliktu. Visnyk Lvivskoho universytetu. Seriia : Mizhnarodni vidnosyny. Lviv, Vyp. 36 (3). S. 13-19.

4. Fesenko M. (2017), Fenomen Vyshehradskoi hrupy v yevropeiskomu politychnomu protsesi. Visnyk Kyivskoho natsionalnoho universytetu imeni Tarasa Shevchenka Mizhnarodni vidnosyny. Kyiv, 1/2 (47/48). S. 13-18.

5. Chekhy, yak i cheska vlada, podileni u stavlenni do Ukrainy. URL: https://www.radiosvoboda.org/a/27497255.html (data zvernennia: 16.01.2020).

6. Iak susidni krainy dopomahaiut Ukraini protystoiaty rosiiskii ahresii. URL: https://ua.112.ua/statji/Yak-susidni-krainy-dopomahaiut-Ukraini-protystoiaty-rosiiskii-ahresii220695.html (data zvernennia: 16.01.2020).

7. Dubsky Z. (2013), Visegrad Cooperation in Military and Security Areas. Is Visegrad still a Central European «Trade Mark»? Bratislava, P. 56-73.

8. Joint Declaration of the Eastern Partnership Summit (Brussels, 24 November 2017). URL: http://www.consilium.europa.eu/media/31758/final-statement-st14821en17.pdf (data zvernennia: 25.11.2017).

9. Joint Statement of the MFAs of the Visegrad Group Countries together with the Minister of Foreign Affairs of the United Kingdom of Great Britain and Northern Ireland to the Local Elections in Donbas held on November 2, 2014. URL: http://www.visegradgroup.eu/calendar/2014/jointstatement-of-the (data zvernennia: 12.01.2020).

10. Joint Statement on Ukraine of the Parliamentary Speakers of the Visegrad Countries Budapest, 28 February 2014. URL: http://www.visegradgroup.eu/calendar/2014 (data zvernennia: 15.10.2018).

11. Joint V4 Foreign Ministers Letter on Ukraine to Ashton and Füle. URL: http://www.visegradgroup.eu/calendar/2014 (data zvernennia: 12.01.2020).

12. The Joint Statement of the Visegrad Group Foreign Ministers on Ukraine. URL: http://www.visegradgroup.eu/calendar/2014/the-joint-statement-of (data zvernennia: 12.01.2020). 